Vol. 1, No. 1, 2020

Yevhen Fornalchyk, Volodymyr Hilevych

Lviv Polytechnic National University

Bandery Str. 12, Lviv, Ukraine, 79000

(C) Fornalchyk Ye., Hilevych V., 2020

https://doi.org/10.23939/tt2020.01.065

\title{
TO DETERMINATION OF TRAFFIC DELAY AT CONTROLLED INTERSECTION
}

\begin{abstract}
Summary. Taking into account the importance of time spent on passing distances of vehicle routes that lie across city road network $(R N)$, well-known approaches to the determination of vehicle delay in the movement process (waiting for passage and the passage) of controlled intersections are analyzed. Reasons that cause the growth of these delays and that have an impact on traffic light cycle duration are counted. At the same time, the authors justify the need for change in the existing term transport delay. It should be interpreted (concerning intersection passage) as a delay only in the case when the group of vehicles that have stopped before intersection could not pass this intersection during the permission signal and wait for the next such signal. If the vehicles in the first group could pass the intersection (possibly taking into account also waiting for the permission signal), then this is not a delay but the necessary component of the technological process of the route passage. From this point of view, an approach in the traffic delay determination method at controlled intersections is proposed taking into account the particular components of Webster's formula and the volume-capacity ratio of $R N$ that determine the motorization level of the city population. A comparison of the results of delay calculation, determined with the use of the proposed method and Webster's formula, is carried out.
\end{abstract}

Key words: vehicle, transport delay, controlled intersection, traffic light cycle, motorization, traffic flow, intensity, saturation flow.

\section{INTRODUCTION}

Controlled intersections are the most vulnerable among transport nodes of city RN. Maximal traffic delays in peak hours are recorded at them, especially if they are located in arterial streets with intensive traffic flows. The reasons of this are the following factors [1-5], starting from too high traffic flow intensities when roadway sizes are not intended for it, unpredictable changes in traffic flow structure, indiscipline of road users (drivers and pedestrians, due to the diversity of their psychophysiological states), ending with the different technical conditions of vehicles (with worn engines that cause the increase of acceleration duration and intersections passage) and also road unevenness near and at intersections. Taking into account some of them, the duration of the traffic light cycle for intersections with appropriate capacity is calculated, the basis of which is minimized transport delays. These delays are calculated by empiric formulas [1,3] and by theoretical formulas [4-9] with values of their components that can be acquired in practice. There exist American, German, and Canadian instructions for the determination of road and intersection capacity, where stop-delays and other delays are evaluated [10-12].

\section{RESEARCH STATEMENT}

Having analyzed a range of scientific publications [5-8, 13], textbooks, manuals, and also different instructions and State standards, it was not established unambiguous interpretation of the term transport delay. Among different interpretations, we can actuate the next term (concerning controlled intersection) [4]: “...this is 
a delay that appears as a result of the reduction of speed of traffic flow movement caused by the traffic light signalization". In previous publications [2-3], we have proved that this (for intersection) is not a delay but the compulsory component of the technological process of the vehicles passage at intersection. That is, waiting time for the passage permission signal by the first group (platoon) and the passage itself are required components. For the next platoon, that did not manage to pass through the intersection, it is a delay. By the terms of queuing theory, traffic flow is served by the traffic light object in the following order: the first platoon of vehicles arrived at the intersection - the first platoon is served just after the permission signal is turned on. For example, the first five vehicles that wait before a stop-line during restrictive signal with duration $t_{r}$, and after turning on the permission signal $t_{p}$ leave the intersection boundaries, is the duration of the technological process of passage, $t_{m . n}=t_{r}+t_{p}$. For the rest of the vehicles in traffic flow that could not pass and will wait for the passage with the duration that is longer than the duration of the traffic light cycle $T_{c}$, it should be qualified as a delay. Its duration will be equal to the duration of restrictive signal $t_{r}$ duration. Such delays will grow for the rest of vehicles in traffic flow depending on the vehicle queue length before the stop-line that can pass during the next permission signals of the traffic light.

\section{RELEVANCE OF RESEARCH AND FORMULATION OF GOALS AND OBJECTIVES}

All previous studies about the analytical determination of traffic flow and determination of traffic flow with the help of software program give diverse values of its duration, especially for a saturation level of movement direction that is close to or bigger than one. That is why, it is appropriate to analyze wellknown methods and techniques in detail and propose more adequate methods based on this analysis which will reproduce the peculiarities of controlled intersections passage more realistically. It should be noted that, by this time, it was not justified in any of the publications, what minimal values of traffic delays should be categorized as a delay.

Therefore, the relevance of the research is that by this time there is no unambiguous interpretation, conception, and analytical or simulated determination of traffic delay values, connected with: a) a passage of vehicles through the intersection (controlled intersection, uncontrolled intersection, roundabout); b) a passage of vehicles on the section between intersections, due to congestion caused by insufficient width of the roadway or sharp growth of traffic intensity, or violation of traffic regulations by road users; c) pullingout of public transport from bus bays; d) vehicles parking on the roadway.

In this study, authors focused on the analytical research of traffic delay associated with controlled intersection passage and are going to fufill the following tasks:

1. To analyze the possibility of using the well-known Webster's formula for this purpose.

2. To develop an approach and the technique of vehicle delay determination, taking into account that passage through the intersection by the first group of vehicles that stopped before the stopline is a compulsory component of the technological process of their movement by the defined route but not the delay; for the rest of vehicles that did not manage to drive through the intersection during the permission signal it is qualified as a delay.

3. To calculate vehicle delay with the proposed technique and Webster`s method and to compare their results.

\section{ANALYSIS OF RECENT RESEARCH AND PUBLICATIONS}

At first, let's analyze (by the example of Webster's formula) an impact of different factors on transport delay. The formula accounts random arrival of vehicles at the controlled intersections [14]:

$$
t_{d e l}=\frac{T_{c}(1-\lambda)^{2}}{2(1-\lambda x)}+\frac{x^{2}}{2 N(1-x)}-0.65\left(\frac{T_{c}}{N^{2}}\right)^{1 / 3} x^{2+5 \lambda},
$$


where $T_{c}$ - traffic light cycle duration, sec; $\lambda$ - the ratio of the duration of permission signal $t_{p}$ to the traffic light cycle duration $T_{c} ; x$ - saturation level of movement direction; $N$ - intensity of passenger car units in the investigated direction, $\mathrm{pcu} / \mathrm{sec}$.

Indicator $x$ can be determined by the formula $x=N T_{u} / S t_{3}$, here $S$ - saturation flow or maximal capacity of movement direction. It is obvious, that this formula works only if the saturation level is limited, $x \leq 0.98$.

It is specified, that the first component of the formula reflects the delay during the regular arrival of vehicles at the intersection, the second component reflects the randomness of this process considering the Poisson process of vehicle arrival, the third component is the empirical correction which increases the accuracy of calculation of the average delay and is approximately $10 \%$ from the value obtained by formula (1) [14].

Foreign and Ukrainian authors stated that delay can be determined adequately only if $x \leq 0.8$. That is why they adopted different amendments for different conditions of intersection passage: for peak period; considering coefficient of variation of traffic flow intensity which can be deterministic or stochastic; dependence only on the restrictive signal, on red and yellow signals; segregation of stop-delays from general delays and other. Concerning software VISSIM, AIVSUM, SIMTRAFFIC and other programs which can determine delay, but they do not provide an opportunity to analyze their internal filling (formulas, dependencies, algorithms). Besides, obtained comparative results of traffic delay, again, do not give the correct answer about which of them reflect realities more adequate: with the use of formulas (analytically) or with the use of software products. Comparisons are made only for different values of saturation level of movement direction $[4,15]$.

We specified [15] that different (changeable) correlation of vehicles of the same type in traffic flow by their operational characteristics (new-worn out) have an impact on traffic delay. The other researchers [16-18] specified that different types of intersections and psychophysiological properties of the driver have an impact on traffic delay.

\section{FORMATION OF A MODEL FOR DETERMINING THE DELAY}

It is obvious, that Webster's formula adequately reflected the realities of traffic delays (the $60 \mathrm{~s}$ of the last century) for appropriate intensities, traffic flow structures, dynamic properties of vehicles, vehicle saturation of cities RN of that time. The current situation with traffic flows differs, firstly, in constant congestion on sections between the intersection and at intersections in peak periods. This, in our opinion, is not because traffic light cycles are justified improperly. The reason is the oversaturation of the city by transport (cars, trucks, buses, trolleybuses, trams, motorcycles, bicycles). If the motorization level, for example, of Lviv at the beginning of 2000 was 110 cars per 1000 citizens, then by the end of 2019 it was 260 cars (not considering all the rest vehicles that every day are in traffic flow composition on city RN). Besides, there is one more important thing: it is impossible to achieve an appropriate proportionality between motorization growth and RN extension under any circumstances (in particular social-economic). Also, it is impossible to stop (reduce the pace) the motorization growth. For partial resolution of the problem with congestion (delays) on $\mathrm{RN}$, the methods of improvement of traffic organization remain and mainly are related with the passage through the intersections in one level.

Therefore, the saturation level of movement direction through the intersection has a direct connection with motorization level $N_{a}$ via traffic intensity $N$ and it is shown in the formula:

$$
x=\frac{N T_{c}}{S t_{r}},
$$

where $S$ - saturation flow (pcu/sec), the base value of which is regulated depending on roadway width $B_{r w}, 5.4 \leq B_{r w} \leq 18.0 \mathrm{~m} ; t_{r}$ - duration of the restrictive signal, sec. 
American technique of saturation flow calculation [10] uses the concept of ideal saturation flow ( $S_{i d}=1900 \mathrm{pcu} / \mathrm{h}$ ) which is adjusted by appropriate coefficients for specific local conditions (width and number of lanes, traffic flow composition, roadway slopes, turns, pedestrian movement, etc.).

From the given formula follows that the more intensity $N$ (and it is connected with motorization level $N_{a}$ ) is for the given saturation level $S$ the more saturation level $x$ is at the appropriate share $\lambda$ of permission signal $t_{p}$ in traffic light cycle duration,

$$
\lambda=t_{r} / T_{c}
$$

That is

$$
x=N / S \lambda
$$

Concerning the intensity of vehicle arrival at the intersection $N$ that is connected with motorization level, then by the data of O. Lobashov [19], it can be presented by volume-capacity ratio $k_{v / c}$ of RN, change of which, depending from motorization level growth, is approximated by the equation

$$
k_{v / c}=0.0039 N_{a}
$$

Then

$$
x=\frac{0.0039 N_{a}}{S \lambda}
$$

As was stated before, the first component of Webster's formula represents the delay for the regular arrival of vehicles at the intersection. Then, for current conditions, we justified [3] that factual delays in the movement should be calculated not with first-pass on the permission signal. For the second and the third platoon that waits in the queue for the passage of intersection (it is established by experimental research that the average amount of vehicles in the platoon is 10 units), it is a real delay. The number of the next restrictive signals $n_{\text {rest }}$ after which the passage through the intersection with appropriate durations $t_{m . n}=t_{r}+t_{p}$ is possible will determine the duration of the delay at one intersection. That is

$$
t_{\text {del }}=n_{\text {rest }}\left(t_{r}+t_{p}\right) \text {. }
$$

As it is unknown whether regular arrival of vehicles at the intersection is fixed during the permission or restrictive signal then in formula (7) it is needed to introduce a saturation degree of movement direction $x$. The last, except saturation flow $S$ and the ratio $\lambda$ of the duration of permission signal $t_{r}$ to the traffic light cycle duration $T_{c}$ will take into account the motorization level. In this case, the duration of vehicle delay before controlled intersection will be determined by the following equation

$$
t_{\text {del }}{ }^{\prime}=n_{\text {rest }}\left(t_{r}+t_{p}\right)+x=n_{\text {rest }}\left(t_{r}+t_{p}\right)+\frac{0.0039 N_{a}}{S \lambda} .
$$

Considering different motorization levels and relevant values of saturation flow and proportion of permission signal, traffic delays for the second and the next groups of vehicles which move in the forward

\begin{tabular}{|c|c|c|c|c|c|c|c|c|c|}
\hline \multirow{2}{*}{$\begin{array}{c}N_{a}, \\
\text { auto/thousand } \\
\text { citizens }\end{array}$} & \multirow{2}{*}{$K_{v / c}$} & \multirow[t]{2}{*}{$T_{c}, \sec$} & \multirow{2}{*}{$\begin{array}{l}t_{p} \\
\text { sec }\end{array}$} & \multirow{2}{*}{$t_{r}, \sec$} & \multirow[t]{2}{*}{$\lambda$} & \multirow{2}{*}{$\begin{array}{c}S, \\
\mathrm{pcu} / \mathrm{h}\end{array}$} & \multicolumn{3}{|c|}{$\begin{array}{l}\text { Delay (sec) for the passage of } \\
\text { vehicle group }\end{array}$} \\
\hline & & & & & & & second & third & fourth \\
\hline 1 & 2 & 3 & 4 & 5 & 6 & 7 & 8 & 9 & 10 \\
\hline \multirow{3}{*}{150} & \multirow{3}{*}{0.585} & 40 & 13 & 27 & 0.3250 & \multirow{3}{*}{1920} & 83.38 & 123.38 & 163.38 \\
\hline & & 60 & 17 & 23 & 0.4250 & & 84.30 & 124.30 & 164.30 \\
\hline & & 80 & 21 & 19 & 0.5250 & & 84.88 & 124.88 & 164.88 \\
\hline
\end{tabular}
direction (for the first it is not a delay but the compulsory component of the technological process of intersection passage) are determined (Table 1).

Table 1

\section{Results of calculation of summarized delays}

for vehicle groups before the intersection that are obtained by the proposed technique 
Table continuation 1

\begin{tabular}{|c|c|c|c|c|c|c|c|c|c|}
\hline 1 & 2 & 3 & 4 & 5 & 6 & 7 & 8 & 9 & 10 \\
\hline \multirow{3}{*}{250} & \multirow{3}{*}{0.975} & 40 & 19 & 41 & 0.3167 & \multirow{3}{*}{1920} & 123.46 & 183.46 & 243.46 \\
\hline & & 60 & 26 & 34 & 0.4333 & & 124.22 & 184.22 & 244.22 \\
\hline & & 80 & 35 & 25 & 0.5833 & & 124.39 & 184.39 & 244.39 \\
\hline \multirow{3}{*}{350} & \multirow{3}{*}{1.365} & 40 & 25 & 55 & 0.3125 & \multirow{3}{*}{1920} & 163.51 & 243.51 & 323.51 \\
\hline & & 60 & 34 & 46 & 0.4250 & & 164.30 & 244.30 & 324.30 \\
\hline & & 80 & 42 & 38 & 0.5250 & & 164.88 & 244.88 & 324.88 \\
\hline
\end{tabular}

From the given above, we can see that, firstly, motorization growth leads to the growth of RN volume-capacity ratio; secondly, it causes the increase of vehicle delay during intersection passage; thirdly, the tendency of delay increase both for motorization growth (vertically) and for priority of passage of vehicle groups (horizontally) remains. For example, for $N_{a}=150$ auto/thousand citizens with $K_{v / c}=0.585$, the minimal value of delay for the passage of the second group of vehicles is $83.38 \mathrm{sec}$ with $T_{c}=40 \mathrm{sec}$, the maximum value is $163.38 \mathrm{sec}$. The increase of traffic light cycle duration to $80 \mathrm{sec}$ causes the increase of delay of vehicles that pass through the intersection in the second group to $84.88 \mathrm{sec}$, i.e. bigger by $1.5 \mathrm{sec}$. The fourth group of vehicles, in comparison with the second group, will have a delay in 1.94 times longer. The same tendencies remain for motorization levels of 250 and 350 auto/thousand citizens.

Let's compare these results with the results which can be obtained using simplified Webster's formula from which the third component is removed that reduces the accuracy by $10 \%$. That is,

$$
t_{d e l}=0.9\left(\frac{T_{c}(1-\lambda)^{2}}{2(1-\lambda x)}+\frac{x^{2}}{2 N(1-x)}\right)
$$

Let's calculate the values for the same duration of the traffic light cycle and permission signals which were used in Table 1 (Table 2).

Also, as an example, let's compare obtained results of $t_{d e l}$ in two tables for traffic light cycle duration $T_{c}=40,60,80 \mathrm{sec}$ with appropriate permission signal duration $t_{p}=17,26,34 \mathrm{sec}$. Let's examine, how $t_{d e l}$ changes for motorization levels $N_{a}=150,250,350$ auto/thousand citizens and traffic flow intensity $N=800$ auto/h (Table 3).

Table 2

\section{Results of calculation of delays for vehicles before intersection that are obtained by Webster`s formula}

\begin{tabular}{|c|c|c|c|c|c|c|}
\hline$T_{c}, \mathrm{sec}$ & $t_{p}, \sec$ & $N, \mathrm{pcu} / \mathrm{h}$ & $S, \mathrm{pcu} / \mathrm{h}$ & $\lambda$ & $x$ & $t_{d e l}, \mathrm{sec}$ \\
\hline \multirow{3}{*}{40} & 13 & 600 & \multirow{3}{*}{1920} & 0.3250 & 0.9615 & 11.95 \\
\hline & 17 & 800 & & 0.4250 & 0.9804 & 10.23 \\
\hline & 21 & 1000 & & 0.5250 & 0.9921 & 8.53 \\
\hline \multirow{3}{*}{60} & 19 & 600 & \multirow{3}{*}{1920} & 0.3167 & 0.9868 & 18.39 \\
\hline & 26 & 800 & & 0.4333 & 0.9615 & 14.88 \\
\hline & 32 & 1000 & & 0.5333 & 0.9766 & 12.29 \\
\hline \multirow{3}{*}{80} & 25 & 600 & \multirow{3}{*}{1920} & 0.3125 & 0.9999 & 32.25 \\
\hline & 34 & 800 & & 0.4250 & 0.9804 & 20.43 \\
\hline & 42 & 1000 & & 0.5250 & 0.9921 & 17.01 \\
\hline
\end{tabular}

Obviously, the longer queue before the intersection is the bigger delays are. For instance, durations of delay for the fourth group of the vehicle exceed delays for the second group in two times. Experimental verification of obtained calculated data confirms this. 
Comparative results of vehicle delay before controlled intersection obtained by the proposed technique and by Webster`s formula (average delays by one vehicle, sec)

\begin{tabular}{|c|c|c|}
\hline \multirow[t]{2}{*}{ For $N_{a}=150$} & $\begin{array}{l}\text { By proposed technique for vehicle group: } \\
-\quad \text { second } \\
-\quad \text { third } \\
-\quad \text { fourth } \\
-\quad \text { average }\end{array}$ & $\begin{array}{c}8.43 \\
12.43 \\
16.43 \\
12.43\end{array}$ \\
\hline & By Webster`s formula & 10.23 \\
\hline \multirow[t]{2}{*}{ For $N_{a}=250$} & $\begin{array}{l}\text { By proposed technique for vehicle group: } \\
-\quad \text { second } \\
-\quad \text { third } \\
-\quad \text { fourth } \\
-\quad \text { average }\end{array}$ & $\begin{array}{l}12.42 \\
18.42 \\
24.42 \\
18.42\end{array}$ \\
\hline & By Webster`s formula & 14.88 \\
\hline \multirow[t]{2}{*}{ For $N_{a}=350$} & $\begin{array}{l}\text { By proposed technique for vehicle group: } \\
-\quad \text { second } \\
-\quad \text { third } \\
-\quad \text { fourth } \\
-\quad \text { average }\end{array}$ & $\begin{array}{l}16.43 \\
24.43 \\
32.43 \\
24.43 \\
\end{array}$ \\
\hline & By Webster`s formula & 20.43 \\
\hline
\end{tabular}

Obviously, the longer queue before the intersection is the bigger delays are. For instance, durations of delay for the fourth group of the vehicle exceed delays for the second group in two times. Experimental verification of obtained calculated data confirms this.

Webster's formula does not examine the order of passage through the controlled intersection by separate groups but gives simultaneous average values of delay that accrue to one vehicle for all traffic flow groups that could pass through the intersection. Therefore, let's compare them with the average values that are obtained for the second, third, and fourth groups of vehicles by the proposed technique. As it can be seen in Table 3, the difference is $2-4 \mathrm{sec}$. But, if to compare with the passage of the fourth group of vehicles for example, then the difference is 6-12 sec. From a standpoint of technological processes design of traffic flow movement (or individual vehicles, for example, buses) on city $\mathrm{RN}$, in particular, motion chronograms, then the proposed technique fully reflects the realities of the important fragment of this process - controlled intersection passage.

\section{CONCLUSIONS AND RESEARCH PERSPECTIVES}

From the given above, we can conclude that the longer the queue of vehicles before he intersection is, the bigger is the duration of the delay and by Webster's formula it cannot be determined. That is the advantage of the proposed technique which adequately reflects practical realities with vehicle delays related to controlled intersection passage. By obtained formula (8) we can more realistically evaluate the delay before controlled intersections with the assumption that equivalent (by the age and technical state) vehicles move in traffic flow.

In further research on this issue it is necessary to take into account firstly, the passage through the intersection by vehicles not only in the forward direction but in all possible ones; secondly, possible priorities that are given to public transport; thirdly, traffic structure in which different types of vehicles with different traction-speed characteristics and driven by drivers with different psychophysiological 
properties. It is also necessary to carry out the computer simulation for delays determination and develop recommendations about the practical use of obtained results.

\section{References}

1. Fornalchyk, Ye. Yu. \& Hilevych, V.V. (2010). Do poniattia "transportna zatrymka" [To the concept "traffic delay". Materialy konferentsii molodykh vchenykh EMT2010 (pp. 64-65). - Lviv: LPNU (in Ukrainian).

2. Fornalchyk, Ye. Yu. \& Hilevych, V.V. (2019). Pro "zatrymky" avtomobiliv i transportnykh potokiv na vyluchno-dorozhnii merezhi mista [About "delays" of vehicles and traffic flows on city road network]. Tezy dopovidei III Vseukrainskoi naukovo-praktychnoi konferentsii "Problemu $z$ transportnymy potokamy $i$ napriamky iikh rozviazannia". (pp. 43-45). - Lviv: LPNU (in Ukrainian).

3. Fornalchyk, Ye. Yu., Kuzio, V. V. \& Hilevych, V.V. (2019). Do vyznachennia zatrymok avtobusiv na marshrutakh [to determination of bus delays on the routes]. Visnyk Natsionalnoho universutety "Lvivska politekhnika". Seriia "Dymanika, mitsnist ta proektuvannia mashyn i pryladiv" [Visnyk of Lviv Polytechnic National University. Series: "Dynamics, strength and design of machines and mechanisms], Volume 910, 125129 [in Ukrainian].

4. Vasilieva, H. Yu. (2007). Metody minimizatsii zatrymok transport na mahistralnii vulychno-dorozhnii merezhi mist Ukrainu [Methods of minimization of transport delays on road network of cities of Ukraine]. Candidate's thesis. Kyiv (in Ukrainian).

5. Fornalchyk, Ye. Yu., Mohula, I. A., Trushevskui, V. E., \& Hilevych, V. V. (2018). Upravlinnia dorozhnim rukhom na rehuliovanykh perekhrestiah u mistakh [Traffic management on controlled intersections in cities]. Lviv: Vydavnytstvo Lvivskoi poitekhniky (in Ukrainian).

6. Hul, A. Ye. \& Stepanchuk, O. V. (2017). Metodu rozrakhunku zatrymky transport [Methods of traffic delays calculation]. Problemy rozvytku miskoho seredovyshcha - Problems of urban environment development. Volume 1(17), 69-77 [in Ukrainian].

7. Labutin, A. S. (2016). Zaderzhki transporta na nereguliruemykh peresecheniakh [Traffic delays on uncontrolled intersections]. Aleya nauki [Alley of science], Volume 3(3), 73-79. (in Russian)

8. Kunytsia, O. A. \& Zakabluk, O.O. (2009). Vuznachennia diisnoi transportnoi zatrymky na nerehuliovanykh perelhrestiakh $\mathrm{v}$ odnomu rivni [Determination of transport delay on uncontrolled intersections in one level]. Visti Avtomobilno-dorozhnioho instytuyu - Visti of Automobile-road institute, Volume 2, 46-51.

9. Stepanchuk, O. V. (2018). Metodolohiia pidvyshchennia efektyvnosti funktsionuvannia vulychnodorozhnoi merezhi mist [Methodology of increase of the effectiveness of cities road network functioning]. Candidate's thesis. Kyiv: KNUBA (in Ukrainian).

10. Highway Capacity Manual / Washington: TRB, 2000. 1134 p.

11. Handbuch fuer die Bemessung von Strassenverkehrsanlagen (HBS 2001). Forshungsgesellschaft fuer Strassenund Verkehrswesen, Koeln, Januar 2002.

12. Teply, S., Allingham, D. I., Richardson, D. B., \& Stephenson, B. W. (2008). Canadian Capacity Guide for Signalized Intersections. Third Edition. Toronto: Institute of Transportation Engineers (in English).

13. Levterov A.I. Denysenko O.V. \& Yaruta A.M. (2013) UA Patent №100660 Sposib vyznachennia zatrymok transportnykh zasobiv na rehulovanomu perekhresti ta prystrii dlia yoho zdiisnennia [Method for determining vehicle delays at a regulated intersection and device for its implementation]. Kharkiv (in Ukrainian)

14. Webster, F.V. \& Cobbe, B. M. (1966). Traffic Signals: Technical Paper № 56. London: Road Research Laboratory (in English).

15. Hilevych, V. V. (2016). Pidvyshchennia efektyvnosti roboty rehuliovanykh perehrest z zhorskymu svitlofornymu tsyklamu [Increase of the effectiveness of controlled intersections operation with fixed-time cycles]. Candidate's thesis. Lviv (in Ukrainian).

16. Hrytsun, O. M. (2016). Doslidzennia transportnykh zatrymok na pidhodakh do rehuliovanykh pishokhidnykh perehodiv za riznykh rezhymiv koordynatsii [Investigation of transport delays on approaches to controlled pedestrian crossings in different coordination regimes]. Visnyk Shidnoukrainskoho natsionalnoho universytetu imeni Volodymyra Dalia [Visnyk of East Ukrainian National University by Volodymyr Dahl], Volume 1 (225), 55-59. (in Ukrainian). 
17. Postranskyy, T. M. (2016). Vpvuv umov rukhu na pokaznyk aktyvnosti rehuliatornykh system vodia miskoho avtobusa [Impact of movement conditions on activity indicator of regulatory systems of city bus driver]. Mizhvuzivskyi zbirnyk "Naukovi notatku" [Intercollegiate collection "Scientific Notes], Volume 55, 310-314. (in Ukrainian).

18. Zhuk, M. M. (2017). Povedinka vodiia za kermom na rehuliovanykh perekhrestiakh [Driver behavior on controlled intersections] Tezy dopovidei II Vseukrainskoi naukovo-praktychnoi konferentsii "Problemu z transportnymy potokamy i napriamky iikh rozviazannia" (pp. 148-151). - Lviv: LPNU (in Ukrainian).

19. Lobashov, A. O. \& Burko, D. L. (2013). Vlianie urovnia avtomobilizatsii na parametru transportnykh potokov [Impact of motorization level on traffic flow parameters]. Tekhnologicheskii audit $i$ rezervu proizvodstva - Technological audit and production reserves. Volume 5(13), 16-19 (in Russian).

Received 27.02.2020; Accepted in revised form 24.03.2020. 